\title{
PENETAPAN KADAR ASAM ASETAT PADA CUKA NIRA AREN (Arenga pinnata Merr.) BERDASARKAN LAMA PENYIMPANAN
}

\author{
Rahmawati ${ }^{1)}$, Nurul Ni'ma Azis ${ }^{1)}$, Lidia Clarita ${ }^{1)}$ \\ ${ }^{1)}$ Prodi D3 Teknologi Laboratorium Medis Politeknik Kesehatan Muhammadiyah Makassar \\ Alamat korespondensi: rahmawatiamma60@gmail.com
}

\begin{abstract}
Abstrak
Pohon aren merupakan tumbuhan yang menghasilkan bahan industriyang dapat diolah menjadi gula, alkohol dan cuka. Sebagian masyarakat mengelolah pohon aren menjadi cuka nira. Cuka nira yang diolah berasal dari nira segar yang telah difermentasikan. Cuka nira yang difermentasi jika disimpan dapat berubah menjadi alkohol sehingga dengan peningkatan keasaman oleh bakteri Acetobacter Acetic akan lebih aktif terjadi perubahan alkohol menjadi asam asetat. Tujuan dari penelitian ini untuk mengetahui kadar pada cuka nira berdasarkan lama penyimpanan. Hasil penelitian dilakukan dengan cara mengukur kadar asam asetat dengan metode titrimetri yaitu alkalimetri menggunakan jenis penelitian eksperimen dengan melakukan standarisasi sebagai konsentrasi tepat untuk melanjutkan pada penetapan kadar asam asetat. Pada penelitian ini menggunakan sampel cuka nira dengan pemberian perlakuan lama penyimpanan selama 1, 4, dan 6 hari, serta dilakukan sebanyak 3 kali perlakuan titrasi. Berdasarkan hasil penetapan kadar pada hari pertama dengan rata-rata 3,68\%, hari keempat $8,89 \%$ dan pada hari keenam 13,86\%, sehingga dapat disimpulkan bahwa terdapat pengaruh kenaikan kadar asam asetat pada sampel dengan lama penyimpanan.
\end{abstract}

Kata Kunci: Minuman tuak, kadar asam asetat, lama penyimpanan, alkalimetri

\section{PENDAHULUAN}

Pohon aren atau enau (Arenga pinnata Merr.) kurang mendapat perhatian untuk dibudidayakan dengan baik oleh berbagai pihak. Pohon aren dari semua bagian dapat digunakan sebagai kebutuhan. Mulai dari akar aren yang cocok sebagai vegetasi yang cocok untuk pencegahan erosi, batang yang keras digunakan sebagai pembuatan alat-alat rumah tangga, daun aren yang terdiri pelepah digunakan sebagai peralatan rumah tangga, tandan buah yang terdapat pada batang menghasilkan nira dan buah nira dapat dijadikan sebagai jajanan kolang-kaling (Prayudi, 2011).

Nira merupakan cairan manis yang diperoleh dari tandan buah yang belum tua dan termasuk produk utama dari tanaman nipah. Konsentrasi gula pada nira nipah berkisar antara 13-17\% (b/v) (Antoni, dkk., 2012). Nira aren dapat dimanfaatkan menjadi minuman segar yang dapat meningkatkan energi atau tenaga dalam bekerja, dan dapat menghangatkan tubuh oleh masyarakat di pedesaan secara tradisional. Nira aren juga difermentasi menjadi semacam minuman beralkohol yang disebut tuak di kalangan masyarakat Sulawesi Selatan khususnya di Kabupaten Gowa. Banyak masyarakat juga mengelola pohon aren menjadi nira yang asam (cuka nira) dan nira yang manis (gula aren).

Adapaun beberapa jenis gula yang terdapat dalam cairan nira seperti glukosa, sukrosa, fruktosa serta karbohidrat lainnya, dengan berbau harum dan $\mathrm{pH}$ berkisar $6-7$. Pada nira segar dapat terjadi pertumbuhan mikroorganisme karena memiliki kadar air berkisar antara 80 $85 \%$ dan sukrosa sekitar $15 \%$. Mikroorganisme yang terdapat pada nira adalah khamir dan bakteri (Yeni, 2011). Bila nira disimpan maka akan terjadi fermentasi oleh adanya mikroorganisme yang terdapat dalam nira sehingga menyebabkan rasa asam (Mardiyah, 2017). Ada dua kelompok penggolongan dari produk nira yaitu kelompok tidak mengalami proses fermentasi dan 
kelompok yang mengalami fermentasi. Cuka, alkohol dan nata merupakan poduk dari nira yang mengalami proses fermentasi. Tahapan fermentasi dari asam cuka dibuat melalui 2 proses yaitu. fermentasi alkohol dengan perubahan glukosa menjadi alkohol oleh Saccharomyces cerevisiae secara anaerob, dan fermentasi asam asetat oleh Acetobacter aceti dengan terjadi proses oksidasi antara alkohol menjadi asam asetat secara aerob. Kedua fermentasi tersebut biasanya dilakukan secara terpisah (Desrosier, 2008).

Nira dapat digunakan sebagai media yang subur untuk pertumbuhan mikroba seperti Acetobacter aceti dan khamir dari genus Saccharomyces karena mengalami fermentasi secara alami, sehingga menyebabkan bakteri lebih aktif mensintesa nira. Cuka nira merupakan salah satu produk dengan biaya dan peralatan yang murah. Produk fermentasi cuka nira adalah produk yang berasal dari nira aren dan akan diolah menjadi arak, alkohol dan nata pinnata (Lempang, 2019). Bila nira disimpan maka akan terjadi fermentasi oleh adanya mikroorganisme yang terdapat dalam nira sehingga menyebabkan rasa asam karena terbentuknya asam asetat dan merupakan media yang baik untuk pertumbuhan mikroorganisme seperti bakteri, kapang maupun khamir (Gusti, 2010).

Penyimpanan nira dapat mengakibatkan meningkatnya aktivitas enzim yang ada didalam nira terutama enzim glukokinase, enzim fosfoglukoisomerase, enzim fosfofrutokinase, enzim aldolase, enzim gliseraldehida-3-P-dehidrogenase, enzim fosfogliseril kinase, enzim enolase, enzim piruvat kinase, enzim piruvat dekarboksilase, enzim dehidrogenase alkohol dan enzim acetobacter acetic sehingga dapat mempercepat terjadinya proses fermentasi (Solikhah, 2011).

Nira aren yang masih segar disimpan dalam bumbung akan mengalami proses fermentasi oleh bakteri
Saccharomyces tuac sehingga nira akan menjadi cuka nira. Cuka nira yang sudah terfermentasi jika disimpan lebih lanjut akan menghasilkan alkohol. Peningkatan kadar alkohol dapat menyebabkan bakteri Acetobacter acetic akan lebih aktif terjadi perubahan alkohol menjadi asam asetat sehingga terjadi peningkatan keasaman cuka nira dan alkohol akan hilang. Fermentasi sukrosa menjadi alkohol berlangsung selama kurang lebih 48 jam, dan jika dibiarkan lagi maka alkohol yang terbentuk berubah menjadi asam asetat (Richana, 2011). Jika asam asetat dalam nira semakin tinggi dan tetap dikonsumsi akan berdampak pada kesehatan seperti pusing, dan terjadi iritasi pada lambung (Syarief, 2009).

Penelitian yang telah dilakukan oleh Pradnyandri, dkk. (2017), menyatakan bahwa dalam jangka waktu yang relatif singkat yaitu penyimpanan selama 1-2 hari tuak aren yang dikonsumsi masyarakat sebagai minuman segar setelah 2 hari dapat dimanfaatkan sebagai cuka. Selama penyimpanan tersebut maka akan tetap terjadi proses fermentasi. Proses fermentasi yang berlangsung menyebabkan sukrosa yang terdapat di dalam nira akan berubah menjadi alkohol dan berlanjut menjadi asam asetat.

Penelitian yang telah dilakukan oleh Leasa dan Matdoan (2015), bahwa lama fermentasi pada cuka nira berpengaruh pada kadar asam asetat. penelitian yang dilakukan dapat diketahui bahwa kadar asam yang rendah terdapat pada lama fermentasi 2 hari dengan kadar asamnya yaitu $2,33 \%$ dan yang paling tinggi adalah lama fermentasi 6 hari dengan kadar asamnya yaitu 4,56\%, masih memenuhi standart SNI 01-3711-1995 tentang kualitas cuka nira dengan ambang batas $4 \%-12,5 \%$.

Berdasarkan penjelasan diatas maka penelitian ini bertujuan untuk menentukan kadar asam asetat pada cuka nira aren (Arenga pinnata Merr.) berdasarkan lama penyimpanan 1, 4, dan 6 hari. 


\section{METODOLOGI PENELITIAN Alat dan Bahan}

Alat yang digunakan pada penelitian ini adalah labu erlenmeyer $250 \mathrm{ml}$, pipet volume $25 \mathrm{ml}$, gelas ukur, labu ukur 100 , labu ukur 500, corong, gelas kimia, cawan petri, pipet tetes, biuret, klem dan statis. Bahan yang digunakan adalah nira, asam oksalat, indikator $\mathrm{PP}, \mathrm{NaOH}$, aquadest, dan tissue.

\section{Prosedur Kerja}

Standarisasi larutan $\mathrm{NaOH} \mathrm{0,1} \mathrm{N}$ dengan larutan $\mathrm{H}_{2} \mathrm{C}_{2} \mathrm{O}_{4}, 2 \mathrm{H}_{2} \mathrm{O}$

Larutan asam oksalat $\left(\mathrm{H}_{2} \mathrm{C}_{2} \mathrm{O}_{4}\right.$. $2 \mathrm{H}_{2} \mathrm{O}$ ) dipipet $25,0 \mathrm{ml}$ lalu dimasukkan ke dalam 3 tabung erlenmeyer $250 \mathrm{ml}$, ditambahkan 3 tetes indikator pp, dititrasi dengan larutan $\mathrm{NaOH}$ sampai timbul warna merah muda yang pertama. Titrasi dihentikan lalu dibaca volume titran dan dihitung normalitas $\mathrm{NaOH}$ yang sebenarnya. Perlakuan diulangi sebanyak $2 \mathrm{x}$.

Rumus perhitungan larutan standar $\mathrm{NaOH}$ dengan Asam Oksalat:

$$
\mathrm{N}=\frac{\text { Berat sampel }(\mathrm{mg})}{\mathrm{BE} \quad \mathrm{x} \quad \text { V. Titran }(\mathrm{mL})}
$$

Keterangan: $\mathrm{N}=$ Normalitas titran

$$
\begin{aligned}
\mathrm{BE} & =\text { Berat Ekivalen } \\
\mathrm{V} & =\text { Volume }
\end{aligned}
$$

\section{Penetapan Kadar Asam Asetat pada Cuka Nira}

Sampel minuman tuak dipipet 50 $\mathrm{ml}$, dimasukkan ke dalam erlenmeyer 250 $\mathrm{ml}$, lalu ditambahkan 3-5 tetes indikator pp. Kemudian dititrasi dengan larutan $\mathrm{NaOH} 0,1 \mathrm{~N}$ sampai terbentuk warna merah muda. Perlakuan diulangi sebanyak 2x.

Rumus penetapan kadar Asam Asetat $\left(\mathrm{CH}_{3} \mathrm{COOH}\right)$ :

$\% \mathrm{CH}_{3} \mathrm{COOH}=\underline{V}$.titran $\times \mathrm{N} x$ BE.sampel x $100 \%$

$$
\text { Keterangan: } \begin{aligned}
\mathrm{V} & =\text { V. Sampel } \\
\mathrm{BE} & =\text { Velume }(\mathrm{mL}) \\
\mathrm{N} & =\text { Normat ekivalen }
\end{aligned}
$$

\section{Analisis Data}

Data yang diperoleh dari hasil penelitian kemudian dianalisis secara deskriptif dan disajikan dalam bentuk tabulasi

\section{HASIL DAN PEMBAHASAN}

Penetapan kadar asam asetat pada cuka nira berdasarkan lama penyimpanan telah di Laboratorium Toksikologi Klinik PolIteknik Kesehatan Muhammadiyah Makassar denagn hasil penelitian yang diperoleh seperti ditunjukkan pada tabel 1 , sebagai berikut:

Tabel 1. Hasil Standarisasi NaOH dengan Asam Oksalat

\begin{tabular}{ccccc}
\hline No & Kode & $\begin{array}{r}\text { Volume } \\
\text { Titrasi }\end{array}$ & Normalitas & Keterangan \\
\hline 1 & E1 & $5,5 \mathrm{~mL}$ & $0,07 \mathrm{~N}$ & Bening - Merah Muda \\
2 & E2 & $3,7 \mathrm{~mL}$ & $0,1 \mathrm{~N}$ & Bening - Merah Muda \\
3 & E3 & $3,8 \mathrm{~mL}$ & $0,1 \mathrm{~N}$ & Bening - Merah Muda \\
\hline \multicolumn{5}{c}{ Normalitas Rata rata } \\
\hline
\end{tabular}

Pada tabel 1 menunjukkan bahwa pada penetapan kadar asam asetat $\left(\mathrm{CH}_{3} \mathrm{COOH}\right)$ pada cuka nira menggunakan larutan titran yaitu larutan standar natrium hidroksida $(\mathrm{NaOH}) . \quad$ Pertama-tama dilakukan standarisasi $\mathrm{NaOH}$ dengan larutan baku primer asam oksalat $\left(\mathrm{H}_{2} \mathrm{C}_{2} \mathrm{O}_{4} \cdot 2 \mathrm{H}_{2} \mathrm{O}\right)$. Larutan oksalat yang digunakan telah ditentukan kadarnya.
Proses titrimetri dilakukan sehingga diperoleh konsentrasi $\mathrm{NaOH}$ secara tepat dengan rata-rata $0,09 \mathrm{~N}$ atau $0,1 \mathrm{~N}$.

Hasil penelitian dalam bentuk volume titran untuk proses titrasi pada cuka nira dengan lama penyimpanan 1,4 , dan 6 hari disajikan pada tabel 2, sebagai berikut: 
Tabel 2. Hasil Volume Rata-rata Titrasi Sampel dengan NaOH 0,1 N

\begin{tabular}{ccccc}
\hline & \multicolumn{4}{c}{ Volume Titrasi } \\
\cline { 3 - 5 } $\mathrm{No}$ & & 1 Hari $(\mathrm{mL})$ & 4 Hari $(\mathrm{mL})$ & 6 Hari $(\mathrm{mL})$ \\
\cline { 2 - 5 } 2 & B1 & $28,4 \mathrm{~mL}$ & $60,7 \mathrm{~mL}$ & $100,5 \mathrm{~mL}$ \\
3 & B2 & $26,8 \mathrm{~mL}$ & $70,8 \mathrm{~mL}$ & $110,3 \mathrm{~mL}$ \\
\hline
\end{tabular}

Pada tabel 2 menunjukkan bahwa pada titrasi alkalimetri dilakukan dengan meneteskan titran $(\mathrm{NaOH})$ yang telah diketahui konsentrasinya secara perlahan ke dalam larutan asam asetat yang belum diketahui konsentrasinya. Pada saat mencapai titik akhir titrasi maka proses titrasi dihentikan. Total volume $\mathrm{NaOH}$ yang digunakan untuk titrasi dapat secara langsung digunakan dalam perhitungan untuk menentukan konsentrasi larutan asam aetat dalam cuka nira seperti yang ditunjukkan pada tabel 3, sebagai berikut:

Tabel 3. Hasil Kadar Rata-rata Asam Asetat dengan Metode Alkalimetri pada Sampel Cuka Nira

\begin{tabular}{ccccc}
\hline No & $\begin{array}{r}\text { Kode } \\
\text { Sampel }\end{array}$ & 1 Hari $\%$ & 4 Hari \% & 6 Hari \% \\
\hline 1 & B1 & $3,40 \%$ & $7,28 \%$ & $12,06 \%$ \\
2 & B2 & $3,21 \%$ & $8,49 \%$ & $13,23 \%$ \\
3 & B3 & $4,45 \%$ & $9,70 \%$ & $15,69 \%$ \\
\hline \multicolumn{2}{r}{ Rata rata } & $3,68 \%$ & $8,89 \%$ & $13,86 \%$ \\
\hline
\end{tabular}

Penetapan kadar asam asetat pada sampel cuka nira dengan penyimpanan selama 6 hari, diberi perlakuan pada hari ke-1, ke-4, dan hari ke-6. Hal ini dilakukan untuk melihat cuka nira yang baik berdasarkan SNI (Standar Nasional Indonesia) 01-3711-1995 tentang kualitas cuka nira bahwa nilai ambang batas $4 \%$ 12,5\%. Standarisasi $\mathrm{NaOH}$ dengan asam oksalat dilakukan sebagai penentuan normalitas yang akan digunakan dalam menghitung penetapan kadar asam. Larutan standar diperlukan untuk menentukan normalitas suatu larutan asam-basa. Larutan standar merupakan larutan denagn konsentrasi yang sudah diketahui dan berfungsi sebagai titran dalam titrasi. Pada tabel hasil larutan standar didapatkan normalitas $\mathrm{NaOH}$ dengan tepat yaitu $0,1 \mathrm{~N}$.

Sampel cuka nira yang diambil pada hari pertama, dibagi ke dalam 3 erlenmeyer dengan volume $50 \mathrm{~mL}$ dan ditambahkan 34 tetes indikator pp yang kemudian dititrasi dengan larutan baku basa $\mathrm{NaOH}$
$0.1 \mathrm{~N}$ yang sudah distandarisasi dimana larutan $\mathrm{NaOH}$ yang bereaksi dengan indikator pp akan menghasilkan perubahan warna dari bening menjadi merah muda sebagai titik akhir titrasi. Kadar asam asetat masing-masing sampel didapatkan secara berturut-turut adalah, 3,40\%, $3,21 \%$, dan 4,45\%. Kemudian sampel pada erlenmeyer dirata-ratakan hingga didapatkan rata-rata sampel adalah 3,68\%. Hal ini dilakukan sebagai pembanding kadar pada cuka nira yang akan diperiksa pada hari ke 4 dan hari ke 6. Perlakuan yang sama diberi pada sampel cuka nira yang akan diperiksa pada hari ke 4 dan ke 6 dan didapatkan kadar asam asetat pada hari ke 4 berturut-turut adalah $7,28 \%, 8,49 \%$, dan $9,70 \%$ dengan rata-rata $8,89 \%$. Perubahan warna dapat ditandai dengan terjadinya perubahan dari bening menjadi ungu pada akhir titrasi. Hal ini disebabkan karena sampel yang disimpan pada hari keempat melewati batas $\mathrm{pH}$ normal asam dan membutuhkan lebih banyak $\mathrm{NaOH}$ sebagai titran dan sampel 
menjadi basa. Sedangkan pada hari keenam didapatkan kadar asam asetat berturut-turut $12,06 \%, 13,23 \%, 15,69 \%$ dengan rata-rata $13,86 \%$. dan tidak terjadi perubahan warna, di sebabkan kadar asam asetat yang melebihi batas normal dan $\mathrm{pH}$ $<7$ sehingga sampel menjadi asam.

Kadar rata-rata asam asetat yang diperiksa di hari pertama dan kadar asam asetat yang disimpan pada hari keempat memiliki kenaikan kadar sebanyak 4\% dan dari kenaikan kadar hari keempat dan hari keenam sebanyak 5\%. Menurut Syarief (2009) menjelaskan bahwa pada semakin lama penyimpanan maka akan banyak tumbuh mikroba dan membelah diri sehingga terjadi peningkatan jumlah dengan cepat. Acetobacter aceti akan lebih aktif untuk mengubah alkohol menjadi asam asetat apabila semakin lama waktu fermentasi sehingga akan semakin tinggi keasaman nira aren. Oleh karena itu, pada proses pembuatan cuka melibatkan proses fermentasi alkohol dan asam asetat secara terus menerus. Fermentasi lanjut dari produk fermentasi alkohol adalah fermentasi cuka atau asam asetat. Sebelum pembuatan cuka bahan baku yang digunakan yaitu nira aren tampak sedikit lebih kental namun setelah mengalami proses fermentasi menjadi cuka, bentuknya menjadi encer dan baunya sangat asam (Syarief, 2009). Menurut Mappiratu dan Bakhri, (2013) tahap awal oksidasi alkohol akan dihasilkan asetatdehid dan tahap selanjutnya menjadi asam cuka atau asam asetat.

Waktu fermentasi merupakan salah satu faktor yang dapat mempengaruhi produk fermentasi asam asetat. Proses fermentasi dengan waktu yang terlalu lama, maka akan terjadi oksidasi asam asetat menjadi karbon dioksida dan air, sedangkan proses fermentasi yang terlalu cepat akan menghasilkan produk yang sedikit karena semua substrat tidak terdegradasi. Perubahan substrat dengan jumlah sedikit menyebabkan bakteri Acetobacter aceti mencari alternative substrat lain sebagai sumber energi untuk beraktivitas yaitu dengan terjadinya oksidasi asam asetat. Penurunan kadar asam asetat dapat terjadi apabila pada proses fermentasi cuka aren tetap berlangsung secara terus menerus karena terjadi oksidasi lanjut oleh asam asetat menjadi karbondioksida dan air.

Analisis kuantitatif dengan metode alkalimetri menunjukkan bahwa kadar asam asetat pada cuka nira tidak melebihi batas normal pada hari ke-1, dan ke-4 dengan kadar asam pada cuka di hari ke-1 adalah 3,68\% dan hari ke-4 8,89\%, sedangkan sampel yang diperiksa pada hari ke-6 melebihi batas normal dengan kadar 13,66\%. Berdasarkan SNI (Standar Nasional Indonesia) 01-3711-1995 tentang kualitas cuka nira telah melewati ambang batas yang ditentukan $4 \%-12,5 \%$, apabila dikonsumsi oleh masyarakat akan menyebabkan dampak merugikan bagi tubuh seperti gangguan pencernaan. Cuka nira yang dikonsumsi dengan kandungan asam asetat dapat meningkatkan produksi asam lambung yang berlebihan gejalanya biasa meliputi mual, nyeri ditempat tertentu, dan didalam perut terasa seperti ada balon gas yang perlahan naik melalui kerongkongan. Asam lambung dibutuhkan dalam kadar yang seimbang untuk proses pencernaan kecuali kadar yang tidak seimbang dapat menyebabkan Gastro Esophagel Reflux Disease (GERD) atau keadaan dimana asam lambung berlebih (Setyaningsih, 2019).

\section{KESIMPULAN}

Penelitian ini telah dilakukan dengan menggunakan metode alkalimetri, sehingga dapat disimpulkan bahwa sampel cuka nira yang diperiksa kadar asam asetat berdasarkan lama peyimpanan dengan perlakuan pada hari 1 dan ke-4 diperoleh rata-rata kadar 3,68\% dan 8,89\%, masih dalam batas normal. Sedangkan sampel yang diperiksa pada hari ke-6 meningkat sangat tinggi dengan kadar 13,86\% sehingga melewati batas normal yang dianjurkan oleh SNI (Standar Nasional Indonesia) 01-3711-1995 dengan ambang batas $4 \%-12,5 \%$. 


\section{SARAN}

Peneliti dapat menyarankan untuk peneliti selanjutnya agar dapat mengembangkan penelitian dengan menggunakan metode lain seperti metode spektofotometer $\mathrm{Uv}-\mathrm{V}$ is pada analisis kuantitatif asam asetat.

\section{UCAPAN TERIMA KASIH}

Peneliti mengucapkan terima kasih kepada Direktur, Kaprodi dan Penanggungjawab Laboratorium Politeknik Kesehatan Muhammadiyah Makassar yang telah memberikan izin penelitian, serta seluruh civitas akademika program studi D3 TLM yang telah membantu terlaksananya seluruh rangkaian penelitian.

\section{DAFTAR PUSTAKA}

Prayudi, F.N.S. Pengaruh Umur Pohon Aren (Arenga Pinnata Merr) Terhadap Produksi Nira Di Desa Pulantan Kecamatan Awayan Kabupaten Balangan Provinsi Kalimantan Selatan. Skripsi Tidak diterbitkan. Fakultas Kehutanan. Universitas Lambung Mangkurat. Samarinda; 2011.

Antoni, R., Chairul dan Hafidawati. Fermentasi Nira Nipah (Nypa Fruticans Wurmb) menjadi Bioetanol menggunakan Kombinasi Pichia Stipitis dan Saccharomyces Cerrevisiae Dalam BIOFLO 2000 Fermentator. Skripsi. Program Studi Teknik Kimia S1 Fakultas Teknik Universitas Riau; 2012.

Yeni, F. Hidayat, A. dan Reni, M., Isolasi dan Aktivitas Fermentasi Bakteri Asam Asetat pada Nira Nipah. Jurnal Pendidikan Matematika dan IPA. 2011: 2 (1): 1-10.

Mardiyah, S. Pengaruh Lama Pemanasan Terhadap Kadar Alkohol Pada Nira Siwalan (Borassus flabellifer). Surabaya: The Journal of
Muhamadiyah Medical Laboratory

Technologist, 2017; 2 (1): 9-15.

Desrosier, N.W., Teknologi Pengawetan Pangan. Jakarta: UI-Press; 2008.

Lempang, M., Rendamen dan Kandungan Nutrisi Nata Pinnata Yang Diolah dari Nira Aren.Pohon Aren Dan Manfaat Produksi nya. Info Teknis EBONI. 2019; 9 (1): 37-54.

Gusti, D. 2010. Isolasi gasohol dari limbah nira aren (Arenga pinnata merr). Jurnal Penelitian Kelapa. 2010; 2 (2).

Sholikhah, F.B.. Pembuatan Patilo, Kajian Lama Fermentasi dan Proporsi Ampas: Pati Ubi Kayu terhadap Karakteristik Fisiko, Kimia dan Organoleptik. Skripsi. Teknologi Hasil Pertanian Universitas Brawijaya. Malang. 2011: 12-14.

Richana, N., Bioetanol: Bahan Baku, Teknologi, Produksi Dan Pengendalian Mutu. Penerbit Nuansa, Bandung. 2011.

Syarief, Beda Cuka Dan Khamir. http://halalsehat.comjournal/item. (14 Januari 2019); 2009.

Pradnyandri, A. Y, Dhyanaputri, G. A. S dan Jirna, N. Kajian Karakteristik Objektif Dan Subjektif Tuak Aren (Arenga pinnata) Berdasarkan Lama Waktu Penyimpanan. Meditory: The Journal of Medical Laboratory. 2017; 5 (1): 13 - 22. http://ejournal.poltekkesdenpasar.ac.id

Leasa, H., dan Matdoan, M.N., Pengaruh Lama Fermentasi Terhadap Total Asam Cuka Aren (Arenga pinnata Merr.) Biopendix, 2015; 1 (2): 135140.

Mappiratu, dan Bakhri, S. Penuntun Praktikum Bioteknologi. Jurusan Kimia Fakultas MIPA Universitas Tadulako. Palu, 2013. 
Setyaningsih. Uji Daya Hambat dari Ekstrak Tanaman Pacar Air

(Impatiens Balsamica L) (ejournal.unsrat.ac.id) diunduh 14 Maret 2019. 2013. 